DOI https://doi.org/10.30525/978-9934-26-004-9-45

\title{
ПРОЯВИ ІДЕЙ НОНКОНФОРМІЗМУ В ЖИВОПИСІ ФЕДОРА МАНАЙЛА (1960-1970-ТІ РР.)
}

\author{
Гаврош О. I. \\ кандидат мистецтвознавства, \\ доцент кафедри культури та соціально-гуманітарних дисциплін \\ Закарпатської академії мистецтв \\ м. Ужгород, Украӥна
}

Альтернативний рух 1960-1980-х pp., який у сучасному мистецтвознавстві визначають як андеграунд, нонконформізм чи неофіційне мистецтво, базувався на пріоритетних засадах власних поглядів усупереч радянським канонам. Якщо в Києві та Львові групування навколо активних реформаторів відбувалося у Клубах творчої молоді ще на початку 1960-х рр. («Сучасник» та «Пролісок»), то в Ужгороді ці процеси активізувалися лишень на початку 1970-х, у часи, які відомий закарпатський поет, лауреат Національної премії ім. Т. Шевченка Петро Мідянка називає «роками чорної маланчуківської реакції» $[1$, с. 31$]$.

Загальний аналіз альтернативного живопису Закарпаття періоду 1970-1980-х pp. розкриває широкий діапазон впливів як світових мистецьких тенденцій, так і особливостей етнокультури Закарпаття. Твори Ф. Манайла, Є. Кремницької, П. Бедзіра, Ф. Семана вирізнялись власною технікою створення композицій, пошуками нових методів формотворення, що радше відповідало стану осяяння. На відміну від художніх проявів у дусі соцреалізму, подібні творчі експерименти асоціювалися з соціальною свободою. Системності офіційного мистецтва була протиставлена хаотичність, незавершеність та спонтанність, що підтверджує стилістика творів, орієнтована на течії, що в СРСР заборонялися (абстракціонізм, сюрреалізм, оп-арт, ташизм). На тлі парадно-офіційного мистецтва у творчості цих художників увага спрямовувалася на особистісну чи індивідуальну тематику. Пошуки нового велися у напрямі віднайдення основ творчості, поновлення втраченого естетично-філософського підгрунтя. Такі процеси творчих відступів суттєво вплинули на формування нової парадигми, що означилася на початку 1990-х. 
Властивим для формування мистецького нонконформізму було залучення традицій народного малярства, повернення до власної ментальності, романтизація духу, пошук нової образотворчої структури тематичного живопису [2, с. 23]. Якщо у 1960-х «суворий стиль» став першою модифікацією соціалістичного реалізму, своєрідною реакцією художників на його вдосконалення, то нонконформісти наповнили живопис індивідуальним світоглядом, що так довго перебував в аморфному стані.

Творчість Ф. Манайла 1960-1970-х рр. є прикладом перших проявів ідей нонконформізму в закарпатському мистецтві. За визначенням Івана Дзюби, Ф. Манайло - легенда нонконформістського мистецького світу кінця 1950 - початку 1960-х рр. [3, с. 136]. У 1970-х у творах художника 3 новою силою зазвучала народна тема, яка у зверненні до глядача не мала риторичного звучання, а сприймалася як діалог із «простим» глядачем на зрозумілій, витриманій часом мові живопису. Картини стали своєрідним контрприкладом до лапідарно-плакатного тематичного живопису, в якому актуальною була стилізація під сучасність. Сцени повсякденного життя, фрагменти селянського побуту Ф. Манайло піднімає до рівня «міських» естетичних та етичних проблем, акцентуючи монументальне і вічне народне духовне начало, фольклорну образність і експресію [4, с. 44].

В останне десятиліття у творчості художника на перший план вийшов живопис, що грунтувався на пошуках у царині пластики та кольору основ його творчої моделі довоєнного періоду. Здається, що художник знов відчув себе повноправним творцем, аніж захопленим спостерігачем, як це було у 1950-1960-х рр. У його міфологічно-філософських творах вивільнився цільний пласт живописних надбань, де наголоси припадали на не прихованих смислах, асоціаціях та ремінісценціях, а на історичному минулому та етнічній ідентифікації традиції. Завдяки сюжету, композиції та кольору твори Ф. Манайла можна сміливо віднести до яскравих прикладів нонконформізму, адже вони випромінюють індивідуальний світогляд митця, насиченість свіжими враженнями та ліберальну відстороненість від нормативів соцреалізму.

Можна припускати, що нонконформізм художника був пов'язаний не 3 позицією протиставлення до соцреалізму, а своєрідним «очищенням» та звільненням від страху бути розчавленим офіційною ідеологічною системою. Виставка «Старе і нове Закарпаття», яка з великим успіхом пройшла у Києві та Москві на початку 1960-х, стала своєрідним маніфестом художника та розірвала пута його внутрішньої ізоляції [5, с. 4]. Етнографізм та декоративізм картин Ф. Манайла, мов образні ін'єкції, стали новим кроком до омолодження закарпатського живопису 
та творчих експериментів молодих незаангажованих художників 3 кольором та формою.

Художник впевнено культивував випрацьований роками варіант станковізму, коли головну роль у створенні образу відігравали специфічні елементи: тональні відкриті кольори, фактура письма, пастозність мазка тощо. «Колядники йдуть», «Князь Лаборець», «Коли у столі було пусто», «Колядки», «Реваш. Вигін скоту» - твори, що засвідчують пластичну активізацію та емоційну наповненість художньої форми. Для досвідченого автора ці процеси не стали мемуаризацією напрацьованих методів, а радше актуалізацією випрацьованої роками власної традиції, в основі якої - звернення до витоків народного мистецтва [6, с. 295]. Жанрові композиції 1970-х не були перевантажені зайвою історико-художньою ерудицією чи енциклопедизмом. Без натяку на сентиментальність у образах автора знов зазвучала драма зачарованого марення ідеями соцреалізму, духовної міграції та штучного інтелектуального світу, в якому ілюзії ідеології витіснили народне буття.

Поступове та програмне насичення живопису філософською проблематикою, як і явною «притчевою» символізацією, у творах Ф. Манайла паралельно розвивалося із монументалізацією образів. Поєднання форми із міфологізацією змісту вимагало від Ф. Манайла відповідного художнього мовлення: трансформації форми, використання метафори, перебільшення та сміливих кольорових співвідношень. Контрастність його ідей вражає, але саме це й стало новим трактуванням, осучасненням уже знайомих 3 довоєнної творчості образів. Його завданням стало вийти за межі існуючої моделі ідеологічного світосприйняття, що згодом дало кілька типологічних напрямів у закарпатському живописі 1970-1980-х рр.: символізацію образів, використання мови народного примітиву, романтичний ідилізм тощо.

Не зважаючи на ідеологічну обумовленість та нормативність закарпатського малярства, у 1970-1980-х в регіональному мистецтві відбувалися процеси актуалізації творчості, що базувалися на парадигмі неофіційного мистецтва. У творах Ф. Манайла, П. Бедзіра, С. Кремницької та Ф. Семана спостерігається відновлення концептуальних зв'язків 3 європейським модернізмом першої половини ХХ ст. та актуальними тенденціями європейського живопису 1960-1980-х. Митці вирішували проблему мистецького пошуку і втілення індивідуальних поглядів у живописі та графіці. При цьому в їхній творчості важливу роль відігравав синтез новітньої художньої мови із інтерпретацією форм народного мистецтва Закарпаття. У цьому вбачаємо продовження пошуків, які розпочали митці-шістдесятники та формування основ руху 
неофольклоризму в середині 1980-х, а також творчі пошуки представників «нової хвилі».

\title{
Література:
}

1. Гаврош О. Закарпатське століття : 20 інтерв'ю. Ужгород: Мистецька лінія, 2006. 318 с. : іл.

2. Смирна Л. Український мистецький нонконформізм : історичний $\mathrm{i}$ світоглядний вимір. Нариси з історії образотворчого мистецтва України ХХ ст.: у 2 кн. Київ: Інтертехнологія, 2006. Кн. 2. С. 5-77.

3. Кіраль С. «...Зробити щось корисне для свого народу» : 3 епістолярної спадщини Івана Чендея: монографія. Ніжин: Видавець ПП Лисенко М. М., 2013. 212 с.

4. Попович М. В. Нарис історії культури України. Київ: АртЕк, $2001.727 \mathrm{c}$.

5. Коцка А. Він любив Закарпаття. Василь Касіян: спогади про художника. К.иїв: Мистецтво, 1986. С. 76-80.

6. Havros O. «Spolieham sa na l'udove umenie» Fedor Manajlo ako interpret folklore / Oksana Havros. Zbornik prispevkov $k$ aktivite: Medzinarodne vedecke symposium $v$ ramci projektu Warhol fest. Medzilaborci, 2006. P. 293-297.

DOI https://doi.org/10.30525/978-9934-26-004-9-46

\section{ПРОБЛЕМИ ЗБЕРЕЖЕННЯ ТА РЕСТАВРАЦІЇ ОЛІЙНИХ РОЗПИСІВ ПАМ'ЯТОК АРХІТЕКТУРИ КИСВО-ПЕЧЕРСЬКОЇ ЛАВРИ}

\author{
Зайцева В. О. \\ аспірант кафедри мистецтвознавчої експертизи \\ Національної академії керівних кадрів культури і мистеитв, \\ стариий науковий співробітник \\ Національного Києво-Печерського історико-культурного заповідника \\ м. Київ, Украӥна
}

На сьогодні справа збереження і реставрації монументального живопису пам'яток архітектури $\epsilon$ однією 3 найскладніших та проблематичних галузей. Це обумовлено як історичними аспектами, пов'язаними 3 пошкодженнями храмів під час бойових дій, занедбанням будівель культового призначення в результаті заборони релігії в 